\title{
In Vitro Anticancer Effect of Gedunin on Human Teratocarcinomal (NTERA-2) Cancer Stem-Like Cells
}

\author{
Luxmiga Tharmarajah, Sameera Ranganath Samarakoon, \\ Meran Keshawa Ediriweera, Poorna Piyathilaka, Kamani Hemamamla Tennekoon, \\ Kanishka Sithira Senathilake, Umapriyatharshini Rajagopalan, \\ Prasanna Bandula Galhena, and Ira Thabrew
}

Institute of Biochemistry, Molecular Biology and Biotechnology, University of Colombo,
90 Cumaratunga Munidasa Mawatha, 03 Colombo, Sri Lanka

Correspondence should be addressed to Sameera Ranganath Samarakoon; sam@ibmbb.cmb.ac.lk

Received 5 April 2017; Accepted 9 May 2017; Published 7 June 2017

Academic Editor: Dong-Wook Han

Copyright (C) 2017 Luxmiga Tharmarajah et al. This is an open access article distributed under the Creative Commons Attribution License, which permits unrestricted use, distribution, and reproduction in any medium, provided the original work is properly cited.

Gedunin is one of the major compounds found in the neem tree (Azadirachta indica). In the present study, antiproliferative potential of gedunin was evaluated in human embryonal carcinoma cells (NTERA-2, a cancer stem cell model) and peripheral blood mononuclear cells (PBMCs), using Sulforhodamine (SRB) and WST-1 assays, respectively. The effects of gedunin on expression of heat shock protein 90 (HSP90), its cochaperone Cdc37, and HSP client proteins (AKT, ErbB2, and HSF1) were evaluated by realtime PCR. Effects of gedunin on apoptosis were evaluated by (a) apoptosis associated morphological changes, (b) caspase 3/7 expression, (c) DNA fragmentation, (d) TUNEL assay, and (e) real-time PCR of apoptosis related genes (Bax, p53, and survivin). Gedunin showed a promising antiproliferative effect in NTERA-2 cells with $\mathrm{IC}_{50}$ values of $14.59,8.49$, and $6.55 \mu \mathrm{g} / \mathrm{mL}$ at 24,48 , and $72 \mathrm{~h}$ after incubations, respectively, while exerting a minimal effect on PBMCs. Expression of HSP90, its client proteins, and survivin was inhibited and Bax and $p 53$ were upregulated by gedunin. Apoptosis related morphological changes, DNA fragmentation, and increased caspase 3/7 activities confirmed the proapoptotic effects of gedunin. Collectively, results indicate that gedunin may be a good drug lead for treatment of chemo and radiotherapy resistant cancer stem cells.

\section{Introduction}

Cancer stem cells (CSCs) are considered as initiators of tumor development and progression [1]. They possess stem cell characteristics such as proliferation, self-renewal, and differentiation into all cell types of the original tumor [2]. These CSCs are resistant to conventional chemotherapy, radiation therapy, and various natural and synthetic anticancer drugs, thus causing relapse of cancer after conventional treatments [3]. Therefore, it is essential to identify novel drug leads that not only target cancer descendant malignant cells, but also target CSCs without damaging normal cells [4]. As CSCs possess some unique dynamics and features, they can be targeted by several methods, including sensitization to natural or synthetic compounds, induction of differentiation into other cell types, and restricting self-renewal [5].
Among clinically approved anticancer drugs, approximately $60 \%$ are natural products derived from plants and microorganisms [6]. The hedgehog, Wnt/ $\beta$-catenin, and Notch-mediated signaling pathways are considerd to be important in CSCs differentiation and self-renewal [7]. Several natural compounds have been reported to target these signaling pathways of CSCs. Cyclopamine, an alkaloid first isolated from Veratrum californicum, has been reported to target hedgehog signaling pathway [8]. Epigallocatechin gallate (EGCG), one of the main compounds in tea, has been reported to inhibit Wnt/ $\beta$-catenin signaling pathway [9]. It has also been reported that Vitamin D and its analogs could inhibit Notch and Wnt/ $\beta$-catenin signaling pathways [10]. Moreover, curcumin and piperine, well-known anticancer compounds, have also been reported to target breast CSCs [11]. 
Gedunin (tetranortriterpenoid) is one of the main chemical compounds found in the neem tree [12]. Recent studies have shown that gedunin can inhibit the proliferation of cancer cells including those of the prostate, ovary, and colon $[13,14]$. It is also reported to be an Hsp90 (heat shock protein 90) inhibitor [15]. Furthermore, a recent in-silico study has revealed drug likeness of gedunin for $\beta$-catenin chain A in cancer stem cells [16]. However, antiproliferative and apoptotic effects of gedunin in cancer stem cells or cancer stem cell model have not yet been evaluated to date. NTERA2 cells are highly pluripotent undifferentiated with cancer stem cell properties [17]. Therefore, the present study was carried out to evaluate the effectiveness of gedunin on human embryonal carcinoma (NTERA-2) cells as a cancer stem cell model.

\section{Methodology}

2.1. General. All the chemicals used in the study were purchased from Sigma-Aldrich (St. Louis, MO, USA) unless otherwise specified. NTERA-2 cell line and all the reagents used for cell culture were purchased from ATCC (Manassas, VA, USA). Gedunin was purchased from Santa Cruz Biotechnology (Santa Cruz, CA). Caspase 3/7 reagent and TUNEL assay kits were purchased from Promega (Promega Corporation, Madison, WI, USA). MESA Green qPCR Master Mix Plus for SYBR Assay was purchased from Eurogentec, Seraing, Liège, Belgium. WST-1 cell proliferation assay kit was purchased from Abcam (Cambridge, MA, USA).

2.2. Cell Culture. The NTERA-2 cells were cultured using Dulbecco's Modified Eagle's Medium (DMEM), supplemented with $10 \%$ fetal bovine serum (FBS), $50 \mathrm{IU} / \mathrm{mL}$ penicillin, and $50 \mu \mathrm{g} / \mathrm{mL}$ streptomycin. Cells were incubated at $37^{\circ} \mathrm{C}$ with $5 \% \mathrm{CO}_{2}$ and $95 \%$ humidity.

2.3. Sulforhodamine B (SRB) Assay. Prior to the SRB assay, NTERA-2 cells were grown in a $75 \mathrm{~cm}^{3}$ flasks. Upon confluency, cells were trypsinized and seeded into 96 -well plates $(5 \times$ $10^{3}$ cells/well). After $24 \mathrm{~h}$ incubation, cells were treated with various concentrations $(3.125,6.25,12.5,25$, and $50 \mu \mathrm{g} / \mathrm{mL})$ of gedunin and retinoic acid (positive control) dissolved in $0.1 \%$ dimethyl sulfoxide (DMSO) and incubated for 24,48 , and $72 \mathrm{~h}$. Negative control for the experiment was $0.1 \%$ DMSO in DMEM medium. Then the cells were fixed with $20 \mu \mathrm{L}$ of $50 \%$ (trichloroacetic acid) TCA and incubated for further $1 \mathrm{~h}$ at $4^{\circ} \mathrm{C}$. After incubation, cells were washed five times with tap water and stained with $50 \mu \mathrm{L}$ of $0.4 \%$ (w/v) SRB solution. After 20 min of incubation, SRB solution was poured off and unbound dye was removed by washing five times with $1 \%$ acetic acid. Bound SRB dye was then solubilized by adding $100 \mu \mathrm{L}$ of Tris base solution. The plates were shaken for $1 \mathrm{~h}$ and absorbance was read at $540 \mathrm{~nm}$ OD.

2.4. Preparation of Peripheral Blood Mononuclear Cells and WST-1 Cell Viability Assay. Cytotoxic effects of gedunin and positive control (retinoic acid) on normal human cells were evaluated by using human peripheral blood mononuclear cells. Collected blood was diluted with Hank's Buffered Salt Solution (HBSS) and layered onto Histopaque 1077. Blood was then centrifuged at $1000 \mathrm{rpm}$ for $10 \mathrm{~min}$. After centrifugation, opaque interface which contains mononuclear cells was seperated and washed with phosphate buffered saline (PBS). Cells were then counted and cultured $\left(2 \times 10^{5}\right.$ cells $\left./ \mathrm{mL}\right)$ in RPMI medium supplemented with $10 \%$ fetal bovine serum (FBS), $50 \mathrm{IU} / \mathrm{mL}$ penicillin, and $50 \mu \mathrm{g} / \mathrm{mL}$ streptomycin in 24-well plates. Cells were then treated with different concentrations of gedunin and retinoic acid dissolved in 0.1\% DMSO $(3.125,6.25,12.5,25$, and $50 \mu \mathrm{g} / \mathrm{mL})$ and incubated for 24 , 48 , and $72 \mathrm{~h}$. Negative control for the experiment was $0.1 \%$ DMSO in RPMI medium. WST-1 cell proliferation assay was then carried out according to manufacturer's instructions to determine the cytotoxic effects.

2.5. Acridine Orange and Ethidium Bromide (AO/EB) Staining. NTERA- 2 cells $\left(2.5 \times 10^{4}\right.$ cells $\left./ \mathrm{mL}\right)$ were cultured on cell culture treated coverslips and incubated for $24 \mathrm{~h}$. Subsequently, cells were exposed to different concentrations of gedunin dissolved in $0.1 \%$ DMSO $(2.5,5$, and $10 \mu \mathrm{g} / \mathrm{mL})$ and incubated for $24 \mathrm{~h}$. Negative control for the experiment was $0.1 \%$ DMSO in DMEM medium. After incubation, cells were fixed using $4 \%$ formaldehyde in the dark for $10 \mathrm{~min}$. Cells were then washed with PBS and stained with ethidium bromide $(100 \mu \mathrm{g} / \mathrm{mL})$ and acridine orange $(100 \mu \mathrm{g} / \mathrm{mL})$ solutions $(1: 1 \mathrm{v} / \mathrm{v})$. Excess dye was then washed off with PBS and cell morphology was observed using a fluorescence microscope (BX51 TRF, Olympus Corporation, Tokyo, Japan).

2.6. TUNEL Assay. Terminal deoxynucleotidyl transferasemediated dUTP-biotin nick-end labeling (TUNEL) staining was carried out to confirm in situ chromatin fragmentation. Cells cultured on coverslips $\left(2.5 \times 10^{4}\right.$ cells $\left./ \mathrm{mL}\right)$ were treated with different concentrations of gedunin dissolved in $0.1 \%$ DMSO $(2.5,5$, and $10 \mu \mathrm{g} / \mathrm{mL})$ and incubated for $24 \mathrm{~h}$. Negative control for the experiment was $0.1 \%$ DMSO in DMEM medium. TUNEL staining was carried out according to manufacturer's instructions. Briefly, cells were fixed with $4 \%$ formaldehyde and permeabilized with $0.2 \%$ Triton X100. Equilibration buffer $(100 \mu \mathrm{L})$ and TdT reaction mix to label DNA were added and incubated for further $60 \mathrm{~min}$ in a humidified chamber. Then coverslips were immersed in $2 \mathrm{x}$ SSC buffer for $15 \mathrm{~min}$ followed by immersing in $0.3 \%$ $\mathrm{H}_{2} \mathrm{O}_{2}$ for $3 \mathrm{~min}$. Finally, labeled fragments were incubated with streptavidin horseradish peroxidase and visualized after diaminobenzidine (DAB) color development where dark brown spots confirmed apoptosis.

2.7. Caspase 3/7 Assay. NTERA-2 cells $\left(2.5 \times 10^{4}\right.$ cells $\left./ \mathrm{mL}\right)$ were cultured in 96-well cell culture plates and incubated for $24 \mathrm{~h}$. After incubation, cells were treated with gedunin dissolved in $0.1 \% \operatorname{DMSO}(2.5,5$, and $10 \mu \mathrm{g} / \mathrm{mL})$ and incubated for further $24 \mathrm{~h}$. Negative control for the experiment was $0.1 \%$ DMSO in DMEM medium. Caspase $3 / 7$ reagent $(100 \mu \mathrm{L})$ was then added to each well and incubated for $1 \mathrm{~h}$ in dark at $37^{\circ} \mathrm{C}$. Luminescence of each well was measured by a plate reader. 
TABLE 1: List of primers used for real-time PCR.

\begin{tabular}{lccc}
\hline ID & Forward primer $\left(5^{\prime}-3^{\prime}\right)$ & Reverse primer $\left(5^{\prime}-3^{\prime}\right)$ & Size \\
\hline HSP90 & CGCTCCTGTCTTCTGGCTTC & TGGTATCATCAGCAGTAGGGTCA & 117 \\
Cdc37 & GGGAGCAGAAAGACAAGACC & GTGGACGTTGTCTGACAGGT & 110 \\
HSF1 & GCCTTCCTGACCAAGCTG & AAGTACTTGGGCAGCACCTC & 134 \\
AKT & TCTATGGCGCTGAGATTGTG & CTTATTGTGCCCGTCCTTGT & 113 \\
ErbB 2 & AGCCGCGAGCACCCAAGT & TTGGTGGGCAGGTAGGTGAGTT & 147 \\
Bax & TCCAGGATCGAGCAGGGCGAA & CGATGCGCTTGAGACACTCGCT & 109 \\
p53 & TCTGGCCCCTCCTCAGCATCTT & TTGGGCAGTGCTCGCTTAGTGC & 369 \\
Survivin & TGGCCGCTCCTCCCTCAGAAAA & GCTGCTGCCTCCAAAGAAAGCG & 190 \\
GAPDH & GGCATTGCCCTCAACGACCAC & ACATGACAAGGTGCGGCTCCCTA & 283 \\
\hline
\end{tabular}

2.8. DNA Fragmentation Analysis. DNA fragmentation analysis was carried out according to previously described methods $[18,19]$. NTERA- 2 cells $\left(2.5 \times 10^{4}\right.$ cells $\left./ \mathrm{mL}\right)$ were grown in cell culture flasks and incubated for $24 \mathrm{~h}$. After incubation, flasks were treated with gedunin dissolved in $0.1 \%$ DMSO $(5,10$, and $15 \mu \mathrm{g} / \mathrm{mL})$ and further incubated for 48 and $72 \mathrm{~h}$. Negative control for the experiment was $0.1 \%$ DMSO in DMEM medium. At the end of the incubation period, cells were trypsinized and cell pellets were obtained. Cell pellets were then incubated for $60 \mathrm{~min}$ at $50^{\circ} \mathrm{C}$ in a $100 \mu \mathrm{L}$ of lysis buffer (100 mM Tris- $\mathrm{HCl}, \mathrm{pH} 8,100 \mathrm{mM} \mathrm{NaCl}$, and $10 \mathrm{mM}$ EDTA). Proteinase $\mathrm{K}(10 \mu \mathrm{L}, 20 \mathrm{mg} / \mathrm{mL})$ was then added to cell lysates and incubated for $30 \mathrm{~min}$ at $50^{\circ} \mathrm{C}$. After adding $3 \mu \mathrm{L}$ of $10 \mathrm{mg} / \mathrm{mL}$ RNase, the mixture was incubated for $2 \mathrm{~h}$ at $50^{\circ} \mathrm{C}$. DNA was extracted in phenol chloroformisoamyl alcohol and $1 \mu \mathrm{g}$ of isolated DNA from each sample was subjected to $2.0 \%$ of agarose gel electrophoresis and visualized under UV using a gel-doc system (Quantum-ST4 1100/20 M).

2.9. Nitrobluetetrazolium Reactive Oxygen Species Assay (ROS). ROS measurement in gedunin treated NTERA-2 cells was carried out using previously described methods [20, 21]. Cells $\left(2 \times 10^{3}\right)$ were cultured in 96-well cell culture plates and incubated for $24 \mathrm{~h}$. After incubation cells were treated with gedunin $(2.5,5$, and $10 \mu \mathrm{g} / \mathrm{mL})$ and incubated for further $24 \mathrm{~h}$. Cells were then incubated with nitrobluetetrazolium $(1 \mathrm{mg} / \mathrm{mL})$ for $1 \mathrm{~h}$ at $37^{\circ} \mathrm{C}$. After the incubation $100 \mu \mathrm{L}$ of DMSO was added to solubilize blue formazan, plates were shaken for $10 \mathrm{~min}$ at room temperature, and the absorbance was read at $620 \mathrm{~nm}$.

2.10. RNA Isolation and Reverse Transcriptase Quantitative Polymerase Chain Reaction (RT-qPCR). NTERA-2 $\left(2.5 \times 10^{5}\right.$ cells $/ \mathrm{mL}$ ) cells were cultured in cell culture flasks and treated with gedunin dissolved in $0.1 \%$ DMSO (5 and $10 \mu \mathrm{g} / \mathrm{mL}$ ) for $24 \mathrm{~h}$. Negative control for the experiment was $0.1 \%$ DMSO in DMEM medium. Following incubation, total RNA was extracted with TRIzol ${ }^{\circledR}$ reagent according to the manufacturer's instructions. For reverse transcription, extracted RNA $(2 \mu \mathrm{g})$ was mixed with $50 \mathrm{ng}$ of random primers and the total volume was made up to $13.5 \mu \mathrm{L}$ with ultrapure water. Resulting mixture was incubated at $70^{\circ} \mathrm{C}$ for $5 \mathrm{~min}$ and, after incubation, it was kept on ice for $2 \mathrm{~min}$. Complementary
DNA (cDNA) was then synthesized by adding $2 \mu \mathrm{L}$ from the transcription mixture, $5 \mu \mathrm{L}$ of $5 \mathrm{x}$ MMLV-buffer, $5 \mu \mathrm{L}$ of $10 \mathrm{mM}$ deoxynucleotide mixture, 25 units of RNasin, and 200 units of MMLV-reverse transcriptase in a reaction mixture of $25 \mu \mathrm{L}$ adjusted by adding ultrapure water and incubated at $37^{\circ} \mathrm{C}$ for $60 \mathrm{~min}$. Real-time PCR was carried out in Stratagene Mx3000P using a master mix containing SYBR green (MESA Green qPCR Master Mix Plus for SYBR Assay). Primers used for real-time PCR are given in Table 1 and glyceraldehyde-3-phosphate dehydrogenase (GAPDH) was used as the internal housekeeping gene. All the real-time PCR reactions contained $2 \mu \mathrm{L}$ cDNA, $0.5 \mu \mathrm{L}$ of each primer (stock concentration $0.5 \mu \mathrm{M}), 12.5 \mu \mathrm{L}$ SYBR Green master mix, and ultrapure water $(9.5 \mu \mathrm{L})$. PCR amplification was performed in triplicate. PCR conditions (for HSP90, Cdc37, and HSF1) were as follows: denaturation step $\left(95^{\circ} \mathrm{C}\right.$ for $\left.10 \mathrm{~min}\right)$ and 40 PCR cycles of three-step amplification (denaturation, $95^{\circ} \mathrm{C}$ for $30 \mathrm{sec}$; annealing, $60^{\circ} \mathrm{C}$ for $1 \mathrm{~min}$; and extension, $72^{\circ} \mathrm{C}$ for $1 \mathrm{~min})$. Annealing temperature was maintained at $58^{\circ} \mathrm{C}$ for 1 min for primers AKT, ErbB2, Bax, p53, and survivin. Results of real-time PCR were analysed using the formula $2^{-\Delta \Delta C t}[22]$.

2.11. Statistical Analysis. GraphPad Prism 5 (GraphPad, Inc., La Jolla, CA, USA) software was used for statistical analysis in the study and results were expressed as the mean \pm standard deviation of three individual experiments. One-way ANOVA with Tukey's post hoc test was used to compare groups and $p<0.05$ was considered as statistically significant.

\section{Results and Discussion}

3.1. Effect of Gedunin on NTERA-2 Cells Proliferation. SRB assay indicated a dose and time dependant inhibition of NTERA-2 cell proliferation once treated with gedunin (Table 2). Cytotoxic effect of gedunin on normal peripheral blood mononuclear cells was not significant as indicated by WST-1 cell viability assay (Table 2 ). Retinoic acid was used as the positive control in antiproliferative cytotoxic evaluations. Gedunin exerted a potential antiproliferative effect on cancer stem cell model NTERA-2 cells when compared to the positive control retinoic acid. Several researchers have also shown antiproliferative effects of certain compounds such as rooperol and RC-6 ribonuclease in NTERA-2 cells in vitro $[17,23]$. 
TABLE 2: $\mathrm{IC}_{50}$ values $(\mu \mathrm{g} / \mathrm{mL})$ of gedunin in NTERA-2 and peripheral blood mononuclear cells at 24,48 , and $72 \mathrm{~h}$ after incubation periods.

\begin{tabular}{|c|c|c|c|c|c|c|}
\hline \multirow{2}{*}{ Cell type } & \multicolumn{3}{|c|}{ Gedunin } & \multicolumn{3}{|c|}{ Retinoic acid } \\
\hline & $24 \mathrm{~h}$ & $48 \mathrm{~h}$ & $72 \mathrm{~h}$ & $24 \mathrm{~h}$ & $48 \mathrm{~h}$ & $72 \mathrm{~h}$ \\
\hline NTERA-2 cells & 14.59 & 8.49 & 6.55 & 14.36 & 9.167 & 6.872 \\
\hline Peripheral blood mononuclear cells & $>100$ & $>100$ & $>100$ & $>100$ & $>100$ & $>100$ \\
\hline
\end{tabular}

3.2. Effects of Gedunin on NTERA-2 Cell Apoptosis. Apoptosis is a cellular process which is responsible for the maintenance of homeostasis of organs and tissues [24]. Deregulation of apoptosis is mainly observed in cancer [25]. Several morphological and biochemical processes are associated with cellular apoptosis [26]. Morphological features associated with apoptosis include condensation of chromatin, reduction in cell volume and shape, nuclear fragmentation, membrane blebbing, and loss of membrane integrity [27]. Biochemical changes associated with apoptosis include activation of caspases, DNA fragmentation, breakdown of proteins, and recognition of cell membrane changes by phagocytic cells [28]. Sequential activation of caspases is one of the major hallmark features of apoptosis [29]. Two classes of caspases, namely, initiators and effectors, have been identified and caspase-3 and caspase-7 belong to the caspase effectors [30]. DNA fragmentation is also considered as a key feature in apoptosis [31]. It is mainly due to the activation of endonucleases which causes cleavage of DNA into internucleosomal fragments [32]. In the present study apoptosis in gedunin treated NTERA-2 cells was evaluated by morphological observations, DNA fragmentation, caspase 3/7 expression, and TUNEL assay.

3.2.1. AO/EB Staining. $\mathrm{AO} / \mathrm{EB}$ staining revealed morphological changes of apoptosis in gedunin treated NTERA-2 cells. Untreated cells were stained in green as these cells take up acridine orange $(\mathrm{AO})$ whereas the cells undergoing apoptosis appeared in yellow/red as these cells take up ethidium bromide (EA) (Figure 1).

3.2.2. CaspaseGlo 3/7 Activity. Caspase 3/7 activity significantly increased in NTERA-2 cells after treatment with gedunin for $24 \mathrm{~h}$. Significant $(p<0.0001)$ increase in caspase $3 / 7$ was observed at two doses (5 and $10 \mu \mathrm{g} / \mathrm{mL}$ ) tested compared to the untreated control (Figure 2). Fold changes observed in caspase $3 / 7$ activity at $2.5,5$, and $10 \mu \mathrm{g} / \mathrm{mL}$ doses of gedunin treated NTERA-2 cells were 1.08, 1.2, and 1.41, respectively.

3.2.3. DNA Fragmentation. DNA fragmentation was observed in NTERA-2 cells exposed to gedunin for 48 and $72 \mathrm{~h}$. A smeared laddering pattern of DNA was observed in the samples treated with 5,10 , and $15 \mu \mathrm{g} / \mathrm{mL}$ of gedunin and positive controls (retinoic acid and thymoquinone). The untreated (control) samples did not show any laddering pattern (Figure 3).

3.2.4. TUNEL Assay. Terminal deoxynucleotidyl transferase (TdT) dUTP Nick-End Labeling (TUNEL) assay has been used to detect apoptotic DNA degradation in late apoptosis. In this method, nicks in degraded DNA are identified by TdT. Gedunin caused increase in the number of TUNEL-positive nuclei at all the doses tested $(2.5,5$, and $10 \mu \mathrm{g} / \mathrm{mL})$ in NTERA2 cells. TUNEL-positive nuclei were not visible in untreated controls (Figure 4).

3.3. Gedunin Caused ROS Generation in NTERA-2 Cells. Significant $(p<0.0001$ and $p<0.001)$ increase in ROS production was observed in gedunin treated NTERA-2 at $24 \mathrm{~h}$ after incubation (Figure 5). Accumulation of ROS plays an important role in induction of apoptosis and cell cycle arrest in cancer cells [33]. Natural compounds such as curcumin, epigallocatechin gallate, parthenolide, quercetin, some phenolic lipids, and quercetin are reported to generate ROS and cause apoptosis in cancer cells [34]. Therefore it is likely that generation of ROS after treatment with gedunin causes apoptosis in NTERA-2 cells.

3.4. Effects of Gedunin on the Expression of Apoptotic Related and Heat Shock Protein (HSP90) and Its Client Protein Genes. Several genes have been reported to exert proapoptotic and antiapoptotic effects in cancer cells [35]. Bax and p53 genes play a pivotal role in apoptosis [36]. Bax is a proapoptotic gene which is known to induce apoptosis in cancer cells [37]. p53 is a tumor suppressor gene with various cellular functions [38]. Induction of apoptosis is one of its main functions [39]. It has been reported that $p 53$ can also regulate the antiapoptotic gene survivin [40]. In the present study, significant $(p<$ $0.05)$ upregulation of $p 53$ was observed in NTERA-2 cells at both doses ( 5 and $10 \mu \mathrm{g} / \mathrm{mL}$ ) of gedunin tested. Upregulation of Bax was also observed in gedunin treated NTERA- 2 cells at both the doses tested. However, regulation of Bax at $8 \mu \mathrm{g} / \mathrm{mL}$ showed a slight reduction compared to the dose of $4 \mu \mathrm{g} / \mathrm{mL}$ (Figure 7). Gedunin also caused significant $(p<0.0001)$ downregulation of proapoptotic gene survivin at both the doses tested in NTRTA-2 cells (Figure 6).

In the present study significant $(p<0.001$ and $p<$ 0.0001 ) downregulation of HSP90 and one of its cochaperones Cdc37 was observed at both the doses ( 5 and $10 \mu \mathrm{g} / \mathrm{mL}$ ) tested in gedunin treated NTERA-2 cells (Figure 7). Significant downregulation $(p<0.001$ and $p<0.0001)$ of HSP90 client proteins (ErbB2, HSF1, and AKT) was also observed in gedunin treated NTERA-2 cells after $24 \mathrm{~h}$ incubation (Figure 7). This observation reveals that gedunin can inhibit the expression of HSP90 and its cochaperon Cdc37 through its client proteins (ErbB2, HSF1, and AKT) in NTERA-2 cells.

Heat shock proteins (HSP) play an important role in cancer development and progression [41]. These proteins are overexpressed in many cancers and they have been 


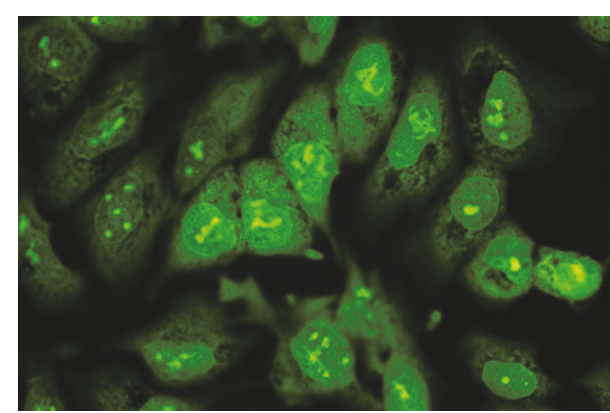

(a)

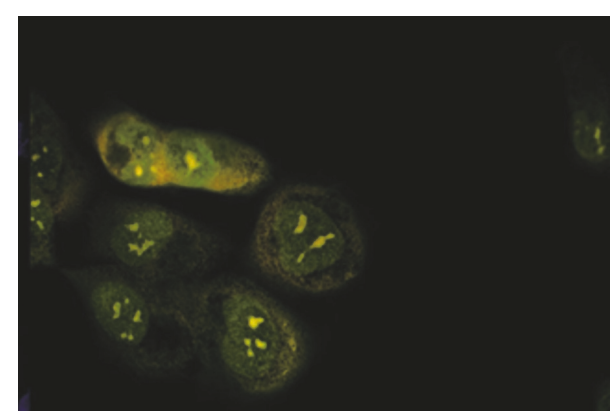

(c)

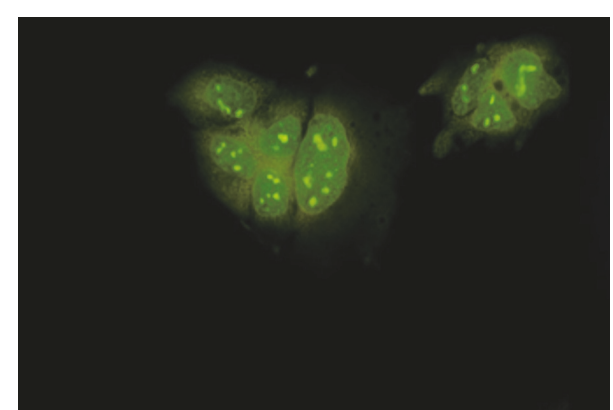

(b)

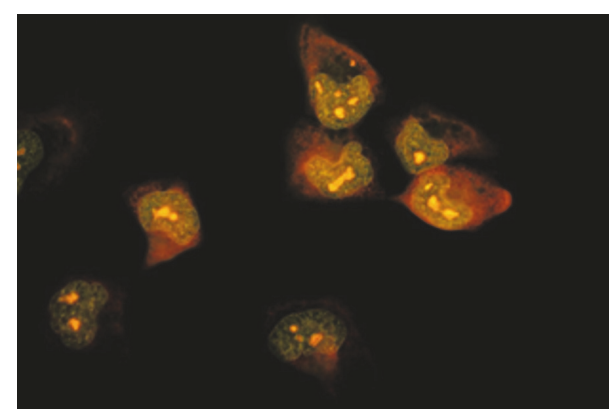

(d)

FIGURE 1: Morphological changes observed under florescence microscope in gedunin treated NTERA-2 cells after staining with AO/EB. (a) Untreated control, (b) cells treated with $2.5 \mu \mathrm{g} / \mathrm{mL}$ of gedunin, (c) cells treated with $5 \mu \mathrm{g} / \mathrm{mL}$ of gedunin, and (d) cells treated with $10 \mu \mathrm{g} / \mathrm{mL}$ of gedunin.

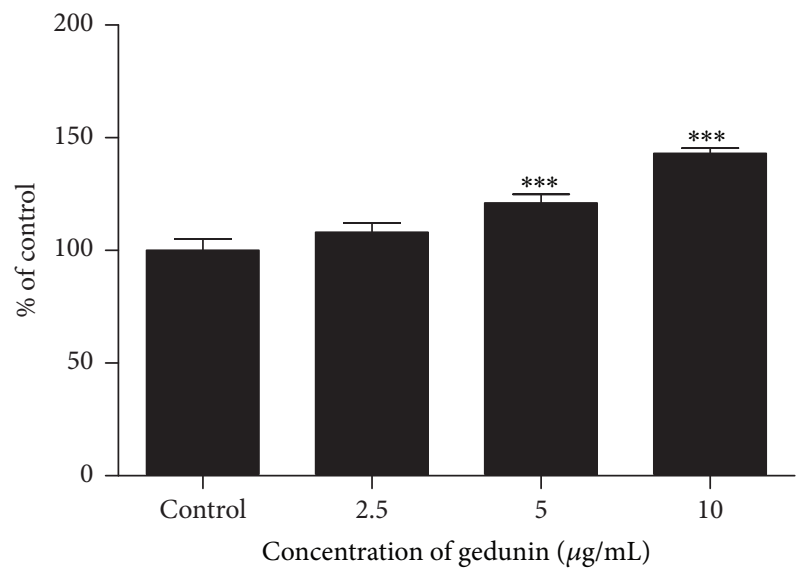

FIGURE 2: Activation of caspase 3/7 in NTERA-2 cells after exposure to gedunin for $24 \mathrm{~h} .{ }^{* * *} p<0.0001$.

mainly targeted in cancer therapy [42]. HSP90 is one of the heat shock proteins reported to function as multichaperone complexes by combining with different cochaperones (Cdc37, p23, Hop, PP5, SGT1, Aha 1, etc.) affecting binding ability of HSP90 to client proteins (AKT, KIT, ErbB2, CDK 4, HSF1, Apaf-1, MMp2, etc.) [43]. Recent studies have confirmed that some natural compounds such as curcumin, quercetin, and taxifolin can inhibit HSP expression cancer cells [44]. A study carried out by Brandt et al. (2008) has demonstrated antiproliferative effects of gedunin and its derivatives in MCFC-7

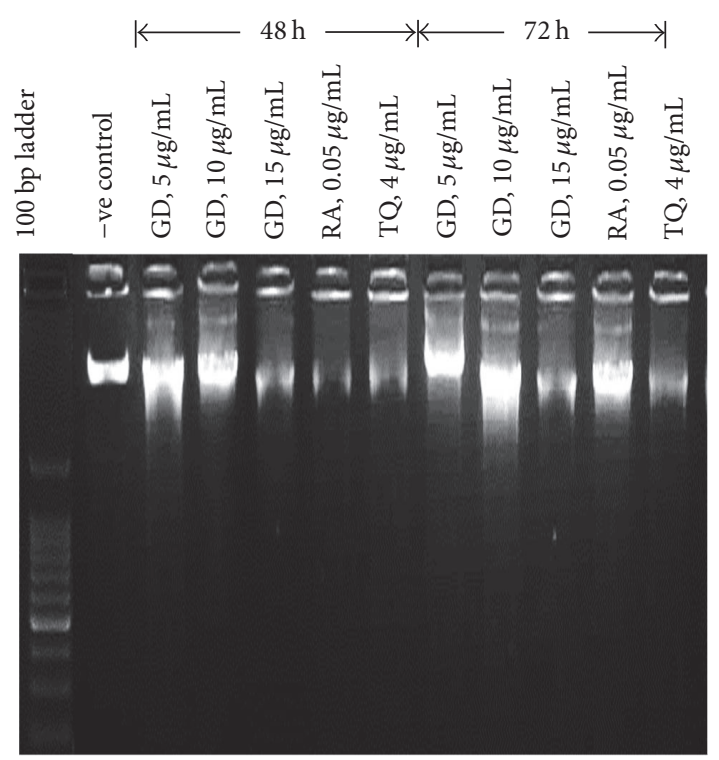

FIGURE 3: DNA fragmentation in gedunin (GD) treated NTERA2 cells. RA and TQ are retinoic acid and thymoquinone (positive controls), respectively. -ve control is untreated cells (0.1\% DMSO).

and SKBR-3 breast cancer cells [45]. Patwardhan et al. (2013) have also demonstrated that gedunin can inhibit the HSP90 chaperone machine through inhibition of its cochaperone p23 [12]. AKT is a signaling molecule/kinase which participates in various cellular functions including apoptosis, cell 


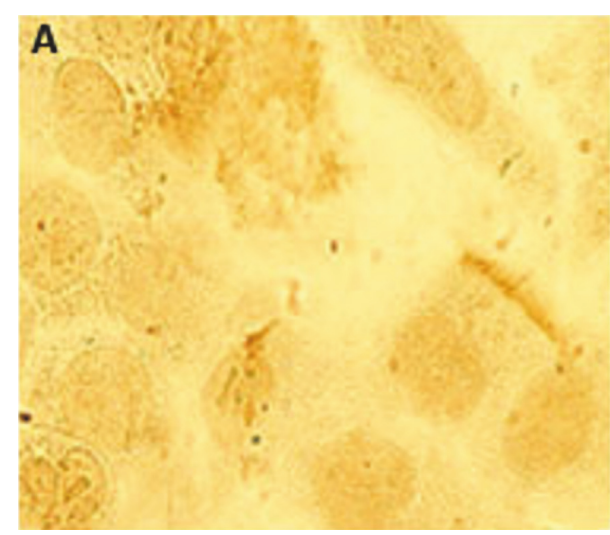

(a)

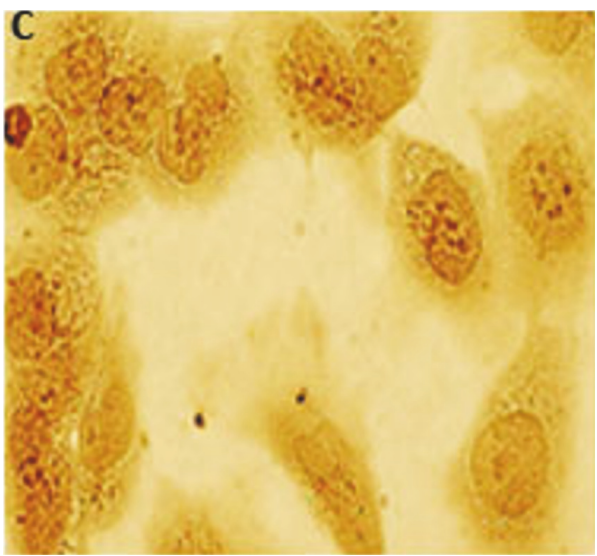

(c)

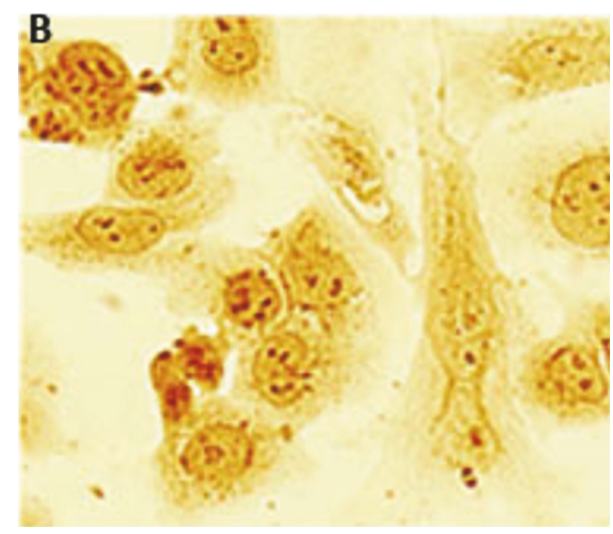

(b)

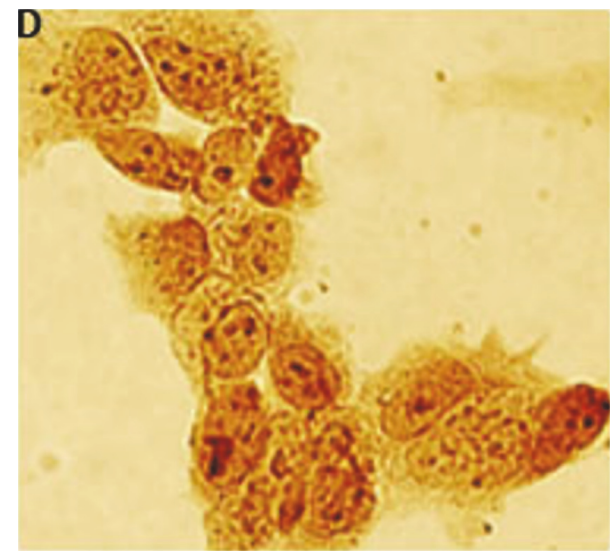

(d)

FIGURE 4: Apoptotic NTERA-2 cells after exposure to gedunin evaluated by TUNEL assay. (a) Untreated control, (b) cells treated with $2.5 \mu \mathrm{g} / \mathrm{mL}$ of gedunin, (c) cells treated with $5 \mu \mathrm{g} / \mathrm{mL}$ of gedunin, and (d) cells treated with $10 \mu \mathrm{g} / \mathrm{mL}$ of gedunin.

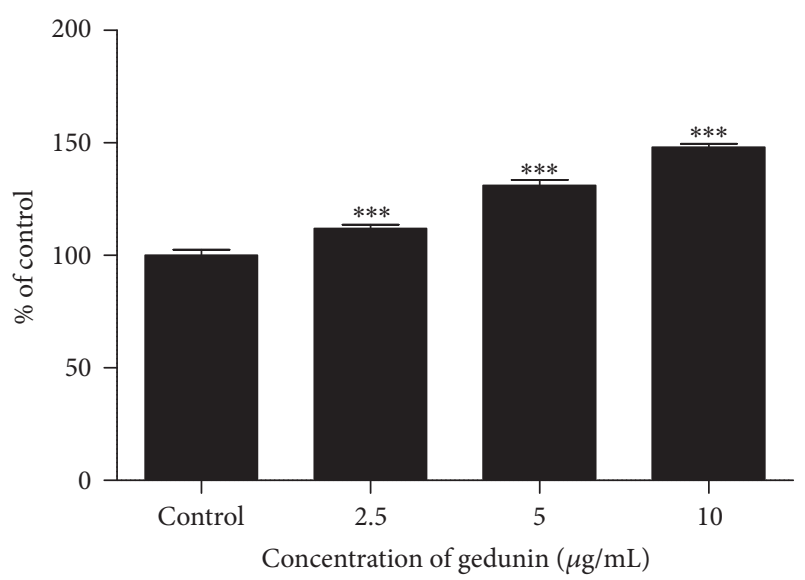

FIGURE 5: Reactive oxygen species (ROS) levels detected in gedunin treated NTERA- 2 cells after $24 \mathrm{~h}$ incubation. ${ }^{* * *} p<0.0001$.

proliferation, metabolism, and cell migration [46]. Inhibition of AKT action is reported to be essential in cancer cell apoptosis [47]. AKT is reported to be overexpressed in cancer cells and stabilized after interacting with HSP90 and one of its cochaperones, Cdc37 [48]. Hence, inhibition of HSP90 and its cochaperone Cdc37 through AKT is likely to cause apoptosis in cancer cells [49]. Human epidermal growth receptor 2 (HER-2/ErbB2) is strongly associated with poor prognosis in cancer [47-50]. It has been reported that ErbB2 activates client protein HSF1 and thereby controls the action of HSP90 in cancer cells [51]. Induction of apoptosis through AKT with the involvement of ErbB2 and HSP90 has also been reported in several studies [52]. Induction of apoptosis via HSP90 inhibition in response to some selected natural compounds has also been demonstrated in several studies $[52,53]$. Apoptotic related genes (Bax, p53, and survivin) to HSP inhibition pathway/s have also been reported. Therefore, according to the results obtained from apoptosis related genes and HSP expression, it is clear that gedunin mediates apoptosis via inhibition of HSP90 and its client proteins in NTERA2 cells. Even though this study presents downregulation of HSP90 client proteins by gedunin at transcription level, there is no supportive evidence in literature regarding inhibition of client proteins of HSP90 at transcription level by other HSP90 inhibitors. Therefore further investigations are needed to confirm regulation of client proteins of HSP90 by gedunin at transcriptional, translational, and posttranslational levels. 


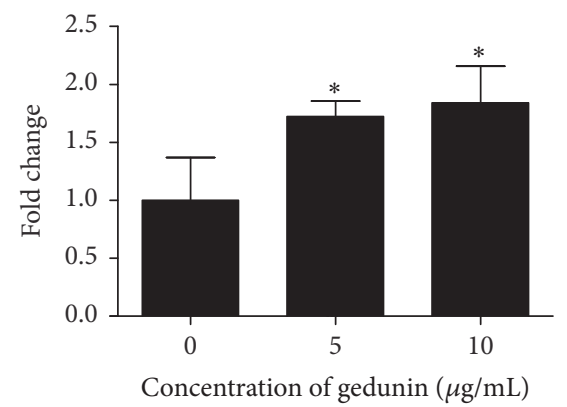

(a)

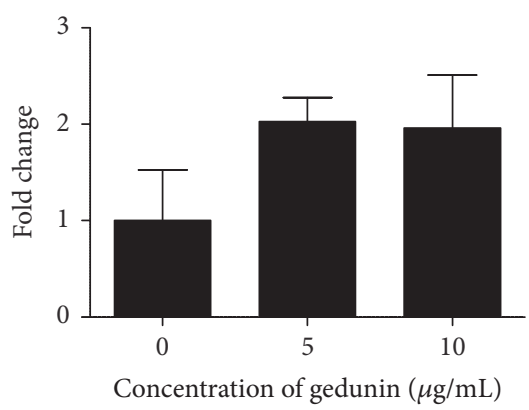

(b)

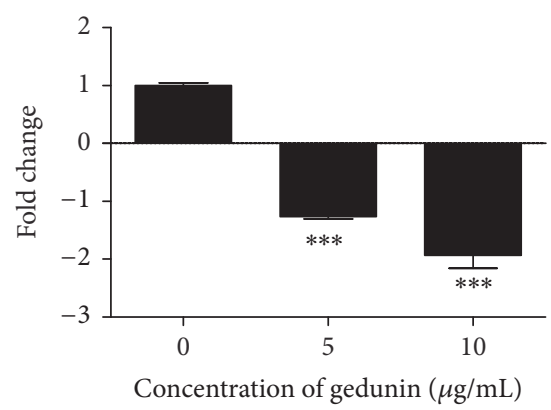

(c)

FIGURE 6: Effects of gedunin on the expression of apoptotic ( $p 53$ and Bax) and antiapoptotic (survivin) related genes. (a) p53, (b) Bax, and (c) survivin. ${ }^{*} p<0.05,{ }^{* * *} p<0.0001$ when compared to untreated controls.

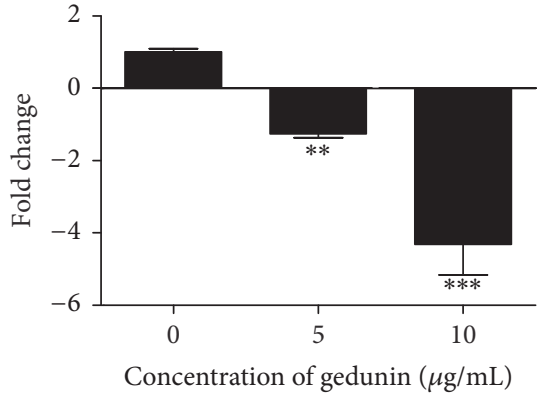

(a)

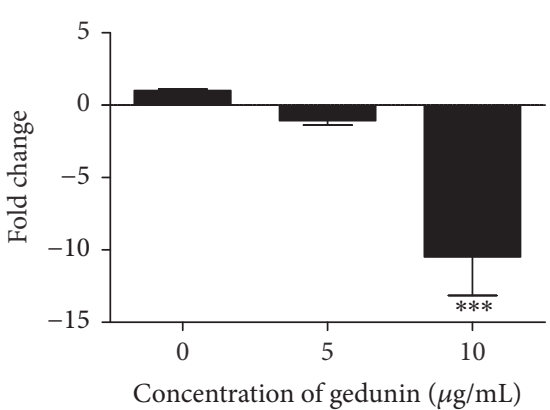

(b)

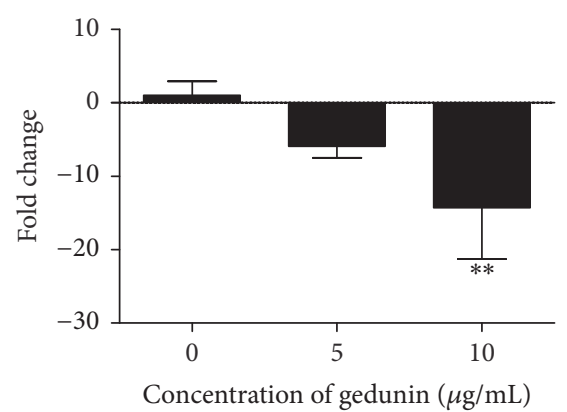

(c)

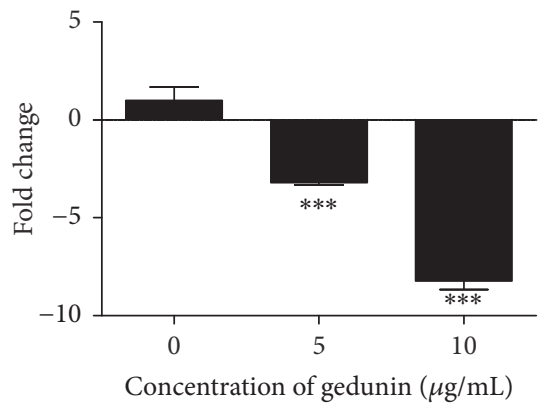

(d)

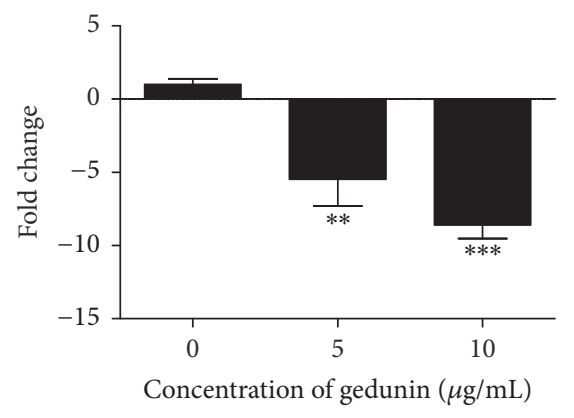

(e)

FIGURE 7: Effects of gedunin on the expression of heat shock protein (HSP90), its cochaperon (Cdc37), and client proteins (ErbB2, HSF1, and AKT). (a) HSP90, (b) Cdc37, (c) HSF1, (d) AKT, and (e) ErbB2. ${ }^{* *} p<0.05,{ }^{* * *} p<0.0001$ when compared to untreated controls.

\section{Conclusion}

Based on the results obtained in the present study, gedunin has the potential to exert antiproliferative effect in NTERA2 cells compared to peripheral blood mononuclear cells. Inhibition of heat shock protein expression (HSP90), its cochaperone and,client proteins appears to be one of the mechanisms used by gedunin to exert antiproliferative and apoptotic effects in the cancer stem cell model, NTERA-2 cells.

\section{Conflicts of Interest}

The authors report no conflicts of interest in this work.

\section{Acknowledgments}

Financial support provided by Institute of Biochemistry, Molecular Biology and Biotechnology, University of Colombo, and National Science Foundation, Sri Lanka (RPHS/2016C07) is gratefully acknowledged.

\section{References}

[1] C. Delude, "Tumorigenesis: testing ground for cancer stem cells," Nature, vol. 480, no. 7377, pp. S43-S45, 2011.

[2] S. Schwitalla, A. A. Fingerle, P. Cammareri et al., "Intestinal tumorigenesis initiated by dedifferentiation and acquisition of stem-cell-like properties," Cell, vol. 152, no. 1-2, pp. 25-38, 2013. 
[3] C. Zhao, A. Chen, C. H. Jamieson et al., "Hedgehog signalling is essential for maintenance of cancer stem cells in myeloid leukaemia," Nature, vol. 458, no. 7239, pp. 776-779, 2009.

[4] X. Lan, Y.-Z. Wu, Y. Wang et al., "CD133 silencing inhibits stemness properties and enhances chemoradiosensitivity in CD133-positive liver cancer stem cells," International Journal of Molecular Medicine, vol. 31, no. 2, pp. 315-324, 2013.

[5] J. Zheng, Y. Li, J. D. Yang et al., "NDRG2 inhibits hepatocellular carcinoma adhesion, migration and invasion by regulating CD24 expression," BMC Cancer, vol. 11, article 251, 2011.

[6] G. M. Cragg, D. J. Newman, and K. M. Snader, "Natural products in drug discovery and development," Journal of Natural Products, vol. 60, no. 1, pp. 52-60, 1997.

[7] S. S. Karhadkar, G. S. Bova, N. Abdallah et al., "Hedgehog signalling in prostate regeneration, neoplasia and metastasis," Nature, vol. 431, no. 7009, pp. 707-712, 2004.

[8] B. E. Batsaikhan, K. Yoshikawa, N. Kurita et al., "Cyclopamine decreased the expression of sonic hedgehog and its downstream genes in colon cancer stem cells," Anticancer Research, vol. 34, no. 11, pp. 6339-6344, 2014.

[9] S. S. Chung and J. V. Vadgama, "Curcumin and epigallocatechin gallate inhibit the cancer stem cell phenotype via downregulation of STAT3-NFאB signaling," Anticancer Research, vol. 35, no. 1, pp. 39-46, 2015.

[10] Q. Shen and S. Christakos, “The vitamin D receptor, Runx2, and the notch signaling pathway cooperate in the transcriptional regulation of osteopontin," Journal of Biological Chemistry, vol. 280, no. 49, pp. 40589-40598, 2005.

[11] M. Kakarala, D. E. Brenner, H. Korkaya et al., "Targeting breast stem cells with the cancer preventive compounds curcumin and piperine," Breast Cancer Research and Treatment, vol. 122, no. 3, pp. 777-785, 2010.

[12] C. A. Patwardhan, A. Fauq, L. B. Peterson, C. Miller, B. S. Blagg, and A. Chadli, "Gedunin inactivates the co-chaperone p23 protein causing cancer cell death by apoptosis," Journal of Biological Chemistry, vol. 288, no. 10, pp. 7313-7325, 2013.

[13] S. J. Uddin, L. Nahar, J. A. Shilpi et al., "Gedunin, a limonoid from Xylocarpus granatum, inhibits the growth of CaCo-2 colon cancer cell line in vitro," Phytotherapy Research, vol. 21, no. 8, pp. 757-761, 2007.

[14] S. G. Kamath, N. Chen, Y. Xiong et al., "Gedunin, a novel natural substance, inhibits ovarian cancer cell proliferation," International Journal of Gynecological Cancer, vol. 19, no. 9, pp. 1564-1569, 2009.

[15] S. Santagata, Y. M. Xu, E. M. Wijeratne et al., "Using the heatshock response to discover anticancer compounds that target protein homeostasis," ACS Chemical Biology, vol. 7, no. 2, pp. 340-349, 2012.

[16] K. Mayan, S. R. Samarakoon, K. H. Tennekoon, A. Siriwardana, and J. R. Valverde, "Evaluation of selected natural compounds for cancer stem cells targeted anti-cancer activity: a molecular docking study," European Journal of Medicinal Plants, vol. 15, no. 4, pp. 1-21, 2016.

[17] S. A. Azouaou, F. Emhemmed, N. Idris-Khodja et al., "Selective ROS-dependent p53-associated anticancer effects of the hypoxoside derivative rooperol on human teratocarcinomal cancer stem-like cells," Investigational New Drugs, vol. 33, no. 1, pp. 6474, 2015.

[18] S. R. Samarakoon, S. B. Kotigala, I. Gammana-Liyanage et al., "Cytotoxic and apoptotic effect of the decoction of the aerial parts of Flueggea leucopyrus on human endometrial carcinoma
(AN3CA) cells," Tropical Journal of Pharmaceutical Research, vol. 13, no. 6, pp. 873-880, 2014.

[19] S. R. Samarakoon, I. Thabrew, B. P. Galhena, and K. H. Tennekoon, "Modulation of apoptosis in human hepatocellular carcinoma (HepG2 cells) by a standardized herbal decoction of Nigella sativa seeds, Hemidesmus indicus roots and Smilax glabra rhizomes with antihepatocarcinogenic effects," BMC Complement and Alternate Medicine, vol. 12, p. 25, 2012.

[20] M. K. Ediriweera, K. H. Tennekoon, S. R. Samarakoon, I. Thabrew, and E. D. de Silva, "Induction of apoptosis in MCF7 breast cancer cells by sri lankan endemic mango (Mangifera zeylanica) fruit peel through oxidative stress and analysis of its phytochemical constituents," Journal of Food Biochemistry, 2016.

[21] T. O. Famuyiwa, A. Boe, J. K. Diaka, J. Jebelli, and N. Esiobu, "Enhancement of genistein-induced apoptosis in LNCaP prostate cancer cells," Journal of Cancer Prevention and Current Research, vol. 4, Article ID 000111, 2016.

[22] K. J. Livak and T. D. Schmittgen, "Analysis of relative gene expression data using real-time quantitative PCR and the $2^{-\Delta \Delta C t}$ method," Methods, vol. 25, no. 4, pp. 402-408, 2001.

[23] G. T. Yiang, H. F. Tsai, J. R. Chen, P. L. Chou, T. K. Wu et al., "RC6 ribonuclease induces caspase activation, cellular senescence and neuron-like morphology in NT2 embryonal carcinoma cells," Oncology Reports, vol. 31, no. 4, pp. 1738-1744, 2014.

[24] X. Jiang, H. Jiang, Z. Shen, and X. Wang, "Activation of mitochondrial protease OMA1 by bax and bak promotes cytochrome c release during apoptosis," Proceedings of the National Academy of Sciences of the United States of America, vol. 111, no. 41, pp. 14782-14787, 2014.

[25] J. Li and J. Yuan, "Caspases in apoptosis and beyond," Oncogene, vol. 27, no. 48, pp. 6194-6206, 2008.

[26] C. Rana, H. Piplani, V. Vaish, B. Nehru, and S. N. Sanyal, "Downregulation of PI3-K/Akt/PTEN pathway and activation of mitochondrial intrinsic apoptosis by Diclofenac and Curcumin in colon cancer," Molecular and Cellular Biochemistry, vol. 402, no. 1-2, pp. 225-241, 2015.

[27] J. Lopez and S. W. G. Tait, "Mitochondrial apoptosis: killing cancer using the enemy within," British Journal of Cancer, vol. 112, pp. 957-962, 2015.

[28] S. Elmore, "Apoptosis: a review of programmed cell death," Toxicologic Pathology, vol. 35, no. 4, pp. 495-516, 2007.

[29] S. Haupt, M. Berger, Z. Goldberg, and Y. Haupt, "Apoptosisthe p53 network," Journal of Cell Science, vol. 116, no. 20, pp. 4077-4085, 2003.

[30] C. Damasio Dde, S. Nolte, L. P. Polak et al., “The lectin BJcuL induces apoptosis through TRAIL expression, caspase cascade activation and mitochondrial membrane permeability in a human colon adenocarcinoma cell line," Toxicon, vol. 90, pp. 299-307, 2014.

[31] J. R. Dynlacht, Z. V. Roberts, M. Earles, J. Henthorn, and J. D. Seno, "Different patterns of DNA fragmentation and degradation of nuclear matrix proteins during apoptosis induced by radiation, hyperthermia or etoposide," Radiation Research, vol. 154 , no. 5, pp. 515-530, 2000.

[32] S. D. Mundle, X. Z. Gao, S. Khan, S. A. Gregory, H. D. Preisler, and A. Raza, "Two in situ labeling techniques reveal different patterns of DNA fragmentation during spontaneous apoptosis in vivo and induced apoptosis in vitro," Anticancer Research, vol. 15, no. 5, pp. 1895-1904, 1995. 
[33] D. Ziech, R. Franco, A. G. Georgakilas et al., "The role of reactive oxygen species and oxidative stress in environmental carcinogenesis and biomarker development," Chemico-Biological Interactions, vol. 188, no. 2, pp. 334-339, 2010.

[34] T. C. Hsieh, D. Halicka, X. Lu et al., "Effects of resveratrol on the G0-G1 transition and cell cycle progression of mitogenically stimulated human lymphocytes," Biochemical and Biophysical Research Communications, vol. 297, no. 5, pp. 1311-1317, 2002.

[35] H. W. Findley, L. Gu, A. M. Yeager, and M. Zhou, "Expression and regulation of $\mathrm{Bcl}-2, \mathrm{Bcl}-\mathrm{xl}$, and Bax correlate with $\mathrm{p} 53$ status and sensitivity to apoptosis in childhood acute lymphoblastic leukemia," Blood, vol. 89, no. 8, pp. 2986-2993, 1997.

[36] A. Mirza, M. McGuirk, T. N. Hockenberry et al., "Human survivin is negatively regulated by wild-type p53 and participates in p53-dependent apoptotic pathway," Oncogene, vol. 21, no. 17, pp. 2613-2622, 2002.

[37] R. J. Youle and A. Strasser, "The BCL-2 protein family: opposing activities that mediate cell death," Nature Reviews Molecular Cell Biology, vol. 9, no. 1, pp. 47-59, 2008.

[38] D. P. Liu, H. Song, and Y. Xu, "A common gain of function of p53 cancer mutants in inducing genetic instability," Oncogene, vol. 29, no. 7, pp. 949-956, 2010.

[39] L. E. Giono and J. J. Manfredi, "The p53 tumor suppressor participates in multiple cell cycle checkpoints," Journal of Cellular Physiology, vol. 209, no. 1, pp. 13-20, 2006.

[40] D. W. Davis, D. A. Weidner, A. Holian, and D. J. McConkey, "Nitric oxide-dependent activation of p53 suppresses bleomycin-induced apoptosis in the lung," Journal of Experimental Medicine, vol. 192, no. 6, pp. 857-869, 2000.

[41] F. Ritossa, "Discovery of the heat shock response," Experientia, vol. 18, no. 2, pp. 97-98, 1966

[42] D. Lanneau, M. Brunet, E. Frisan, E. Solary, M. Fontenay, and C. Garrido, "Heat shock proteins: essential proteins for apoptosis regulation," Journal of Cellular and Molecular Medicine, vol. 12, no. 3, pp. 743-761, 2008.

[43] L. Whitesell and S. L. Lindquist, "HSP90 and the chaperoning of cancer," Nature Reviews Cancer, vol. 5, no. 10, pp. 761-772, 2005.

[44] C. M. Palermo, C. A. Westlake, and T. A. Gasiewicz, "Epigallocatechin gallate inhibits aryl hydrocarbon receptor gene transcription through an indirect mechanism involving binding to a $90 \mathrm{kDa}$ heat shock protein," Biochemistry, vol. 44, no. 13, pp. 5041-5052, 2005.

[45] G. E. L. Brandt, T. E. Schmidt, and B. S. J. Blagg, "Gedunin, a novel Hsp90 inhibitor: semisynthesis of derivatives and preliminary structureactivity relationships," Journal of Medicinal Chemistry, vol. 51, no. 20, pp. 6495-6502, 2008.

[46] Y. Okawa, T. Hideshima, P. Steed et al., "SNX-2112, a selective Hsp90 inhibitor, potently inhibits tumor cell growth, angiogenesis, and osteoclastogenesis in multiple myeloma and other hematologic tumors by abrogating signaling via Akt and ERK," Blood, vol. 113, no. 4, pp. 846-855, 2009.

[47] L. Whitesell, E. G. Mimnaugh, B. De Costa, C. E. Myers, and L. M. Neckers, "Inhibition of heat shock protein HSP90pp60v-src heteroprotein complex formation by benzoquinone ansamycins: essential role for stress proteins in oncogenic transformation," Proceedings of the National Academy of Sciences of the United States of America, vol. 91, no. 18, pp. 8324-8328, 1994.

[48] G. Chen, P. Cao, and D. V. Goeddel, "TNF-induced recruitment and activation of the IKK complex require Cdc37 and Hsp90," Molecular Cell, vol. 9, no. 2, pp. 401-410, 2002.
[49] W. B. Pratt and D. O. Toft, "Regulation of signaling protein function and trafficking by the hsp90/hsp70-based chaperone machinery," Experimental Biology and Medicine, vol. 228, no. 2, pp. 111-133, 2003.

[50] L. Shang and T. B. Tomasi, "The heat shock protein 90-CDC37 chaperone complex is required for signaling by types I and II interferons," The Journal of Biological Chemistry, vol. 281, no. 4, pp. 1876-1884, 2006.

[51] A. Citri, B. S. Kochupurakkal, and Y. Yarden, "The Achilles heel of ErbB-2/HER2: Regulation by the Hsp90 chaperone machine and potential for pharmacological intervention," Cell Cycle, vol. 3, no. 1, pp. 51-60, 2004.

[52] J. Davenport, J. R. Manjarrez, L. Peterson, B. Krumm, B. S. J. Blagg, and R. L. Matts, "Gambogic acid, a natural product inhibitor of Hsp90," Journal of Natural Products, vol. 74, no. 5, pp. 1085-1092, 2011.

[53] Y. Li, T. Zhang, Y. Jiang, H.-F. Lee, S. J. Schwartz, and D. Sun, "(-)-Epigallocatechin-3-gallate inhibits Hsp90 function by impairing Hsp90 association with cochaperones in pancreatic cancer cell line mia paca-2," Molecular Pharmaceutics, vol. 6, no. 4, pp. 1152-1159, 2009. 

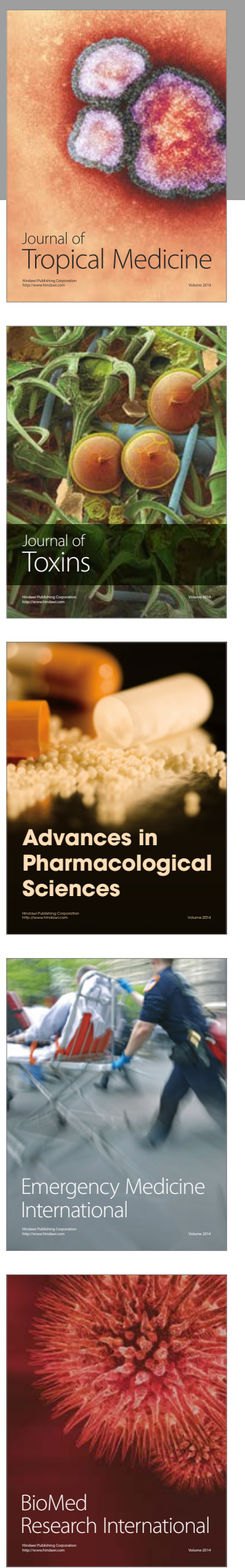
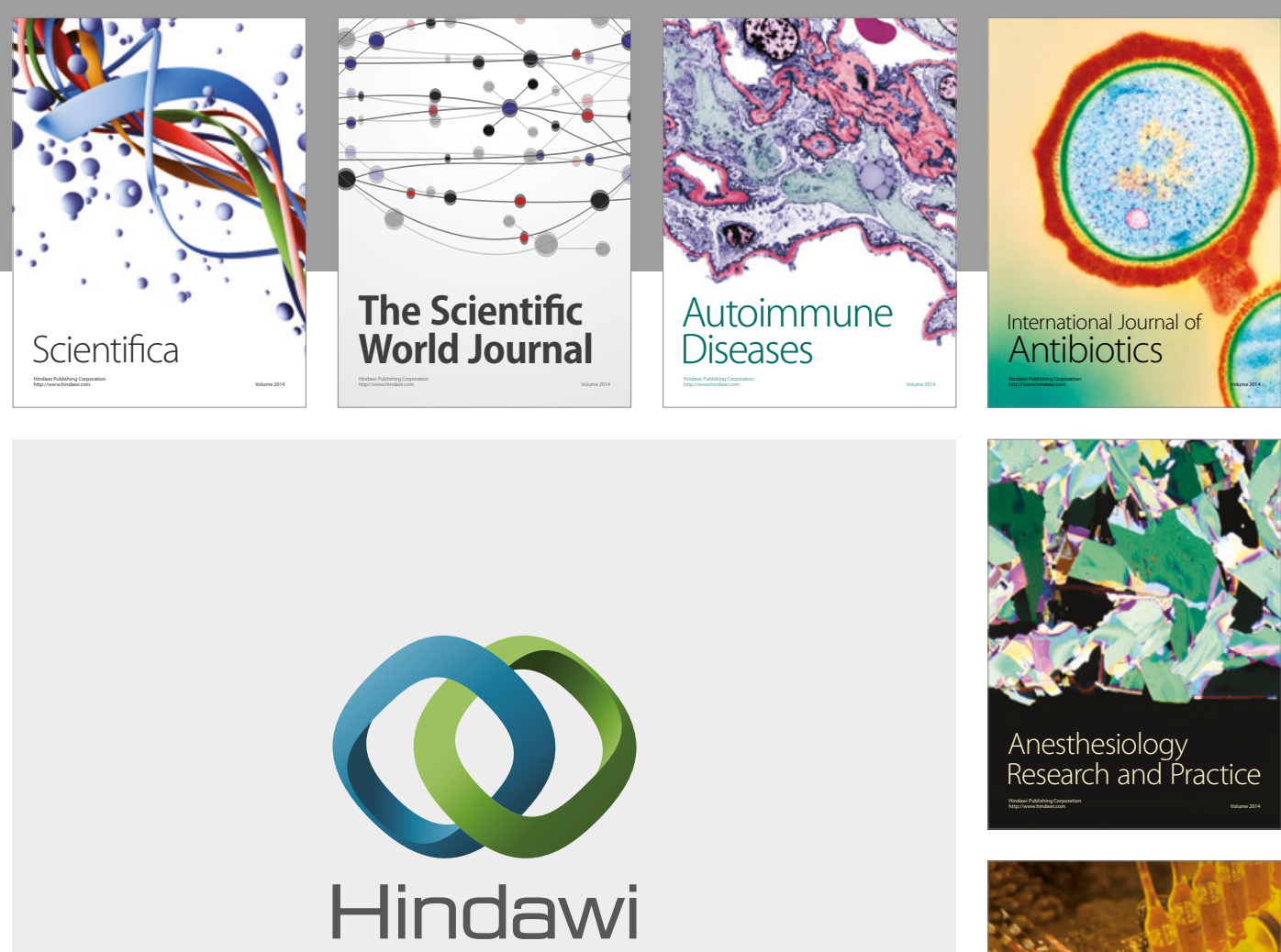

Submit your manuscripts at

https://www.hindawi.com
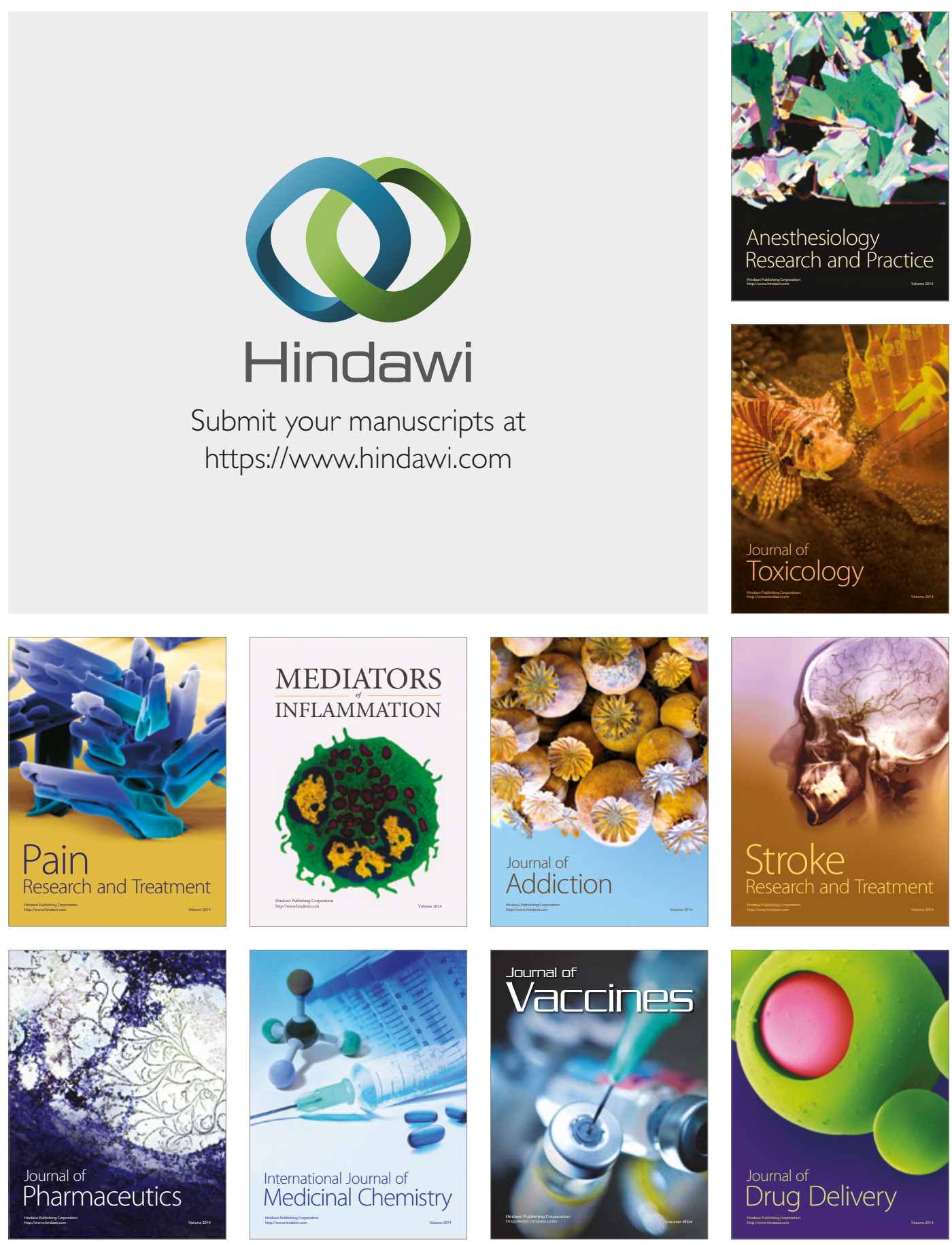